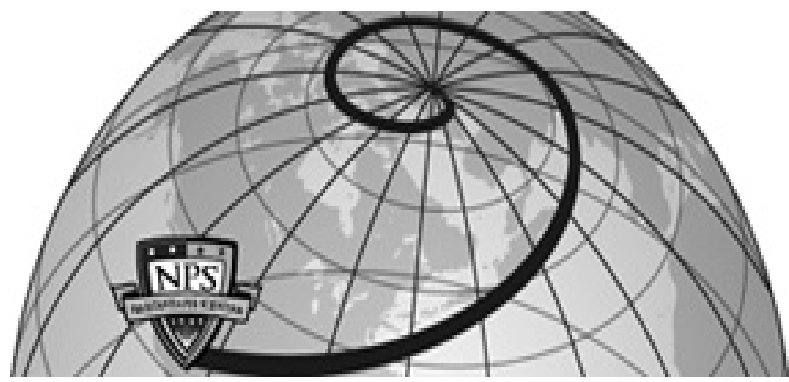

Calhoun: The NPS Institutional Archive DSpace Repository

\title{
The Impact of Military Expenditures on Human Capital Development in the Arab World
}

Looney, Robert E.

Monterey, California: Naval Postgraduate School.

https://hdl.handle.net/10945/38028

Downloaded from NPS Archive: Calhoun

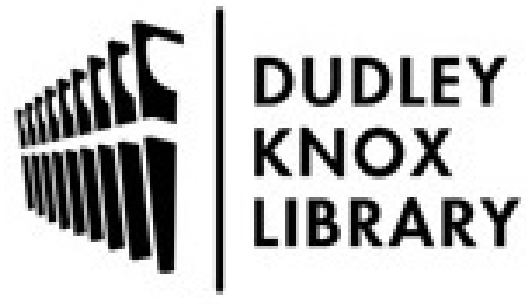

http://www.nps.edu/library
Calhoun is the Naval Postgraduate School's public access digital repository for research materials and institutional publications created by the NPS community. Calhoun is named for Professor of Mathematics Guy K. Calhoun, NPS's first appointed -- and published -- scholarly author.

Dudley Knox Library / Naval Postgraduate School 411 Dyer Road / 1 University Circle Monterey, California USA 93943 


\section{The Impact of Military Expenditures on Human Capital Development in the Arab World}

The Impact of Military Expenditures

Robert E. Looney

Naval Postgraduate School, Monterey, California, USA

\section{Introduction}

It is often argued[1] that the post-1973/74 expansion in military expenditures undertaken by the Persian Gulf states has led to competition between the military and civilian sectors for skilled labour. Furthermore, military expenditures are said to have pre-empted funds that might otherwise have been allocated to education and the improvement of human capital. It is argued that, as a result, military expenditures in the region tended to frustrate the oil exporters' ambitious economic development programmes, especially those of the less-populated oilexporting countries.

Another view was originally presented by Stephanie Neuman[2, p. 588] in her analysis of the situation in pre-revolutionary Iran. According to Neuman, some of the skills taught by the military benefit the civilian sector. As she points out, however, a question still remains as to:

... how one would distinguish between the military and the civilian costs and benefits. What is the net balance over the long and short term? Furthermore, how are the skill levels related to the kinds of military technology imported? Does more technology demand higher skills and, therefore, indirectly upgrade the educational level of the country? Instead, does it draw away needed skilled manpower from the civilian sector?[2, p. 589].

Clearly the ability of these countries to adapt to changing and, in most cases, more austere economic environments will depend in large part on how effectively they took advantage of the abundant revenue years to increase the education and skills of their domestic workforces.

The purpose of this article is to address the question of whether military expenditures in the Arab world have been made at the expense of national human resource development. Based on this analysis, several implications are drawn as to the dynamics of human capital development in that region of the world.

\section{Manpower Shortages and Government Expenditures}

Human capital accumulation can be stimulated in developing countries through public education expenditures as well as Government spending on health and other social services. Clearly governments are the most important agencies in this area and can do much more than private enterprises could ever hope to achieve.

ternational Journal of Manpower. bl. 13 No. 3, 1992, pp. 35-48. (c) MICB University Press, 0143-7720 
International Journal of Manpower 13,3
Government initiative in this area has expanded in recent years with Arab countries as a whole increasing their educational expenditures as a percentage (see Table I) of GNP from 3.87 per cent (1974) to 5.47 per cent (1987)[3]. Health expenditures have not shown such a dramatic increase, however, increasing from 1.39 per cent of GNP (1974) for the Arab countries to 1.72 per cent (1987). A similar pattern was observed for the non-Arab countries, spending less than their Arab counterparts for each of the years examined but slightly more (as a share of GNP) on health than their Arab counterparts.

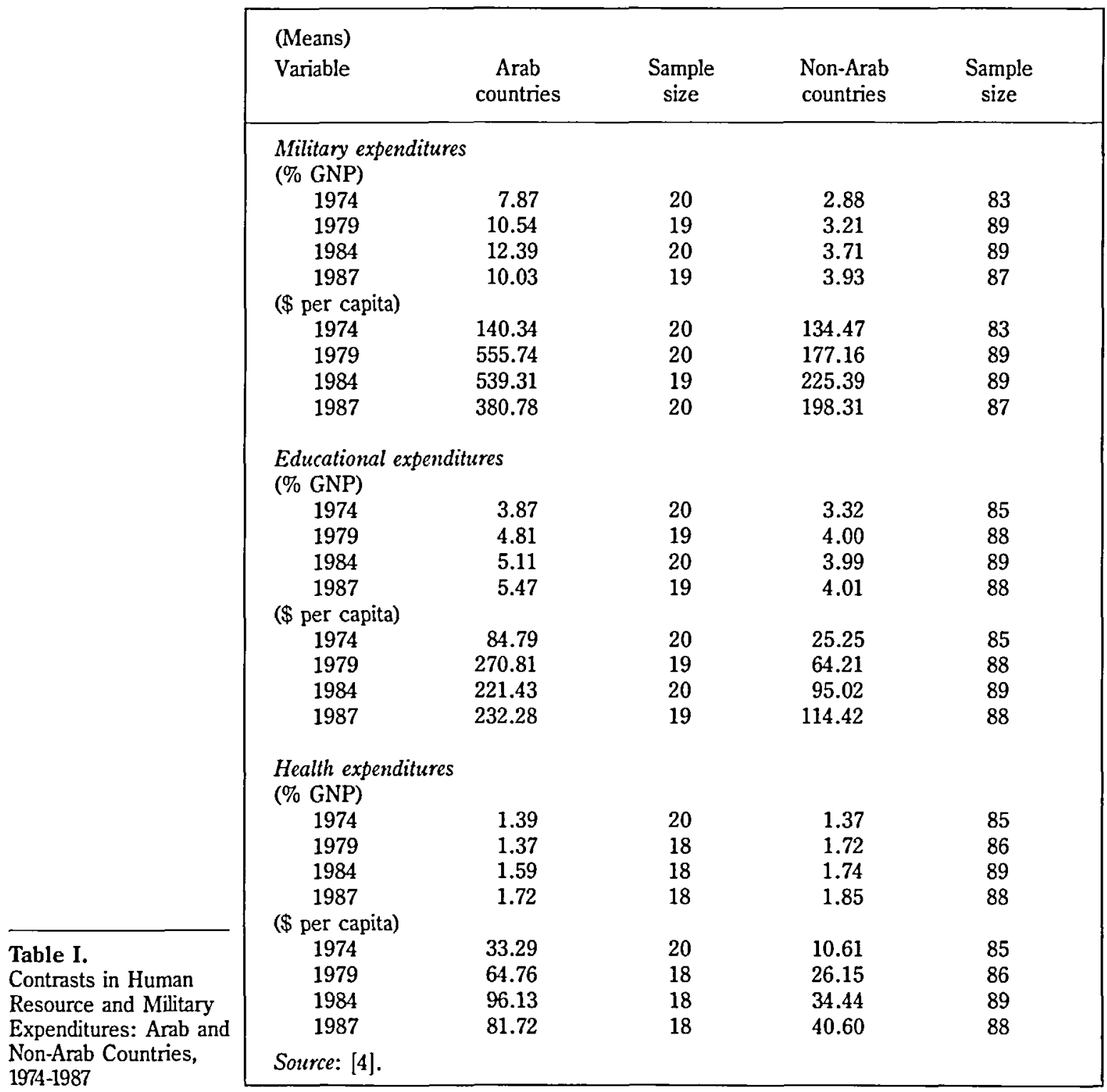


On the other hand, the governments of developing countries also have extremely strong commitments to military expenditure to bolster security and counter threats. Aggregated defence expenditure is almost always state-induced and the consumption of scarce resources to support the military as well as reallocation of valuable inputs into arms production must generally be provided for in the national budget. In terms of general magnitudes, Arab countries expanded their allocations to defence from 7.87 per cent in 1974 to 12.39 per cent in 1985, only to contract to 10.03 per cent in 1987. Militarization in the non-Arab countries has not been nearly so dramatic, with defence expenditures in these countries increasing from 3.01 per cent in 1974 to 3.71 per cent in 1984 and 3.93 per cent in 1987.

In short, concurrent with rapid economic growth in the Arab world, a relatively large share of resources has been allocated to the military. For the Arab region as a whole military purchases have been partially financed by oil revenues and by military aid and grants from the major industrial country arms suppliers. Lebovic and Ishaq[5, p. 107] have noted that, while absolute regional military spending has been phenomenal, the military also controlled a greater percentage of the central Government budget in the Middle East - twice as much of the national output as in other developing countries or in the world as a whole.

Middle Eastern defence accounted for one-third of the military spending of developing countries and almost one-half of world arms imports. During the 1973-82 period, the average annual economic growth rate for the individual Middle Eastern states was about 6 per cent, while military expenditures grew by approximately 13 per cent per annum. Although military expenditure levels vary greatly across countries, in a great majority of the countries the growth rate of military spending outpaced economic growth. This indicates a striking trend in the region towards higher military burdens (military expenditures as a ratio of gross domestic product)[5, p. 107].

As Lebovic and Ishaq $[5$, p. 107] point out, besides the simple guns-versusbutter trade-off, economic theory does not unambiguously indicate whether a higher military burden retards or promotes economic growth. As noted earlier, empirical evidence on the subject has become the focus of considerable controversy. In this regard, Charles Wolf[6] has noted:

Military and paramilitary forces can contribute to economic development by their contributions to internal and external stability. Moreover, the real economic costs imposed by the military on developing countries can be reduced to the extent that these forces provide training, construction, technological and industrial spill-overs that contribute to economic growth. Evidence in support of both of these propositions is provided by the experience of several of the successfully modemizing countries during the past decade.

Along these lines, Weede has found considerable empirical support for the proposition that increased military participation rates increase overall economic growth[7, p. 17]:

In my view, the positive effect of military service on the economic performance should be explained as follows: the military teaches discipline and creates a useful habit of obeying orders. Where the military participation ratios are high, the military is more likely to be disciplined

\section{The Impact of Military Expenditures}


International Journal of Manpower 13,3 and effective than elsewhere, since there is a perceived need to be on the alert against foreign enemies. Moreover, the higher the military participation ratio, the more young men acquire discipline and obedience. That is why I regard the military participation ratio as a disciplinerelated indicator of human capital formation, why I suggest to broaden the notion of human capital formation so as to include abilities and discipline.

Clearly, the Arab world, given its relatively low levels of human capital formation, should be one of the areas most receptive to this link between military expenditures, military participation, human capital formation and economic growth.

However, in their study of the relationship between defence burdens and growth in the Middle East, Lebovic and Ishaq[5, p. 136] found in general the relationship was negative for the non-oil-exporting countries, but that no statistically significant pattern existed for the total sample (17 countries). The negative finding is consistent with those obtained by Frederiksen and Looney[8], who make a distinction between resource-constrained and resource-abundant countries.

Given the small sample sizes of oil producers in the Middle East, Lebovic and Ishaq were not able to test for any potential positive relationships between defence expenditures and economic growth, a relationship found by Frederiksen and Looney $[9,10,11]$ for larger samples of developing countries. These positive relationships have, however, been identified through time-series analysis for selected countries and over periods of time.

For example, in the case of Saudi Arabia it was found that[12]:

(1) In general, military expenditures have had a net positive impact on the country's overall gross capital formation. That is, after controlling for Government expenditures and oil revenues, increases in military expenditures have had a net stimulating effect on investment in the Kingdom. The same also applies to non-oil investment. Here, however, the strength of defence expenditures was low compared with that of Government investment.

(2) Military expenditures do not appear to stimulate either total private-sector expenditures or consumption. Again Government investment appears particularly productive in contributing to increased levels of private-sector consumption.

(3) Military expenditures do not appear to induce levels of imports nearly so much as do the overall levels of Government expenditures or oil revenues.

(4) Interestingly enough, military expenditures appear to induce privatesector investment, whereas Government investment seems to crowd out or pre-empt resources that might otherwise flow towards this sector.

(5) On average, military expenditures appear to contribute more to overall demand than does Government consumption. The stimulating effect of military expenditures on other types of Government expenditures tends to reinforce this effect. 
In short, military expenditures in the Saudi Arabian context appear to have (in addition to their security value) a number of significant impacts on the privatesector, not all of which are negative. In particular, several of the major areas of private-sector activity appear to derive more of a stimulus from particular Government expenditures than from other types of public allocations. The same also appears to apply to the overall level of gross capital formation and non-oil investment.

In addition, these results suggest that a careful shifting of Government allocations from public-sector consumption to capital formation (providing that profitable areas for investment have not been exhausted), rather than acrossthe-board reductions in military expenditures, is the most productive policy open to the authorities for contributing to private-sector expansion.

In a slightly different context, it has been suggested that excessive defence expenditures led to the economic instability preceding the Iranian Revolution. While this argument sounds quite plausible, research by Neuman noted above together with several cross-section studies $[9,11]$ have reached the counterintuitive conclusion that Iran may have actually derived a number of beneficial economic impacts from allocations to the military. However, cross-sectional analysis looks at only one point in time, and hence its results are always sensitive to the dates chosen for examination.

To assess if time-series analysis provides a different perspective on the impact of the country's military expenditures, another time-series study[13] attempted to quantify the impact of military expenditures on the Iranian economy over the 1959-77 period, and in particular the consequences associated with the rapid military build-up undertaken by the Shah in the mid-1970s.

The main findings of this study suggested that, while a case could be made that the economy received positive net benefits from defence expenditures in the $1960 \mathrm{~s}$, this relationship broke down in the $1970 \mathrm{~s}$, with added military expenditures, perhaps through the bottlenecks they created, having a negative impact on a number of sectors and types of capital formation. Interestingly enough, these negative effects were not systematically associated with other types of Government expenditures, indicating that the Government's allocations to defence were unique in their marginal negative impact on private-sector output after the 1973/74 revenue boom.

Again, these findings are consistent with cross-section analysis, which indicates that resource-constrained countries generally experience negative impacts from military expenditures, while those not constrained by foreign exchange and/or domestic savings are capable of experiencing positive impacts from increased allocations to defence.

Looking at the impact of military expenditures from a different perspective, that of labour scarcity, Cummings et al. [1, pp. 38-49] note that labour shortages in the Gulf states, created by expanded military expenditures, may be a far greater long-term impediment to growth in the region than any effects associated with the diversion of capital or foreign exchange to military activities. In a somewhat similar manner, Mousad[14] found that a 10 per cent reduction in the military spending ratio (percentage of GNP) - or a decrease of around
The Impact of Military Expenditures 
International

Journal

of Manpower

13,3
$\$ 12.9$ billion - would increase education expenditures by around $\$ 8.1$ billion per year.

Along these lines, Deger[15] estimated that a 15 per cent reduction in the share of the military spending ratio, i.e. from 6.3 per cent of gross domestic product to 5.4 per cent (approximately $\$ 13$ billion in absolute terms) would increase the allocation of funds to education by about $\$ 4.5$ billion a year. These estimates were made for developing countries as a whole, with no distinction made between countries as being resource-abundant or resource-constrained, labour-abundant or labour-scarce and so on.

The purpose of the analysis below is to extend several strands of the analysis surveyed above. Specifically, we are primarily interested in examining the Arab states, a set of countries characterized as generally having (by Third World standards) very high military burdens (defence expenditures as a percentage of gross national product) together with lower than average levels of human capital. In addition we are interested in determining whether and to what extent military expenditures act independently of total Government expenditures in affecting human capital development in the region. Finally, are the linkages between military expenditures and human capital development in the Arab world fundamentally different from those experienced in other parts of the developing world? If so, why?

\section{Framework for Analysis}

The main measurable variables pertain to allocations to defence, Government expenditures and public education that generate human capital. In her study of education/defence trade-offs Deger[15] used the share of education in gross national product as a proxy for human capital development. This measure is rather arbitrary, and it is not clear from the theoretical literature whether human capital formation is best measured as an input (financial) or as an output (in terms of learning attainment, attendance, etc.[16]). In a broader sense human capital also includes factors such as health/medical care, etc.

To avoid these definitional problems, factor analysis was used to develop a composite measure of human capital[17]. As a preliminary step, the factor analysis was performed on a sample of socio-economic measures developed by Ruth Sivard[4]. To obtain some sense of variations over time, the years 1974, 1977, 1980 and 1987 were selected for the factor analysis.

A second step involved including the military participation rate (armed forces per capita) in the factor analysis[18]. Here we were interested in determining the extent to which military participation was competitive with or complemented human capital development[19]. This preliminary examination of our total sample of Third World countries[20] produced several interesting patterns (see Tables II and III):

(1) For 1987 (the last year for which comparable data were available) three[21] main factors were identified: human capital, public expenditure and a dimension reflecting the share of national resources allocated to education. The human capital factor comprised largely performance measures - literacy rates, teachers; and to a lesser extent health - physicians per capita.

(2) At this time (1987) the military participation rate (armed forces per capita) was only weakly loaded on human capital and public expenditures. That 
is, countries that had higher levels of military participation did not have significantly higher levels of human capital development or resources allocated by the national authorities.

(3) The same picture emerged in 1980, with the military participation rate again associated with human capital development and public expenditure. The factor loadings on this date were, however, somewhat higher than those observed in 1987.

(4) In contrast the $1970 \mathrm{~s}(1974,1977)$ saw the military participation rate largely associated with public expenditures. That is countries that had high levels of public expenditures were apparently able also to afford committing relatively large numbers of their populations to the military.

\begin{tabular}{|c|c|c|c|}
\hline $\begin{array}{l}\text { (Factor loadings) } \\
\text { Variable }\end{array}$ & $\begin{array}{l}\text { Factor } 1 \\
\text { Human } \\
\text { capital }\end{array}$ & $\begin{array}{l}\text { Factor } 2 \\
\text { Public } \\
\text { expenditure }\end{array}$ & $\begin{array}{l}\text { Factor } 3 \\
\text { Educational } \\
\text { commitment }\end{array}$ \\
\hline \multicolumn{4}{|l|}{ Total sample of countries, 1987} \\
\hline Literacy rate, males & $0.924^{*}$ & 0.078 & 0.083 \\
\hline Literacy rate, females & $0.931^{*}$ & 0.037 & 0.330 \\
\hline School age population per teacher & $-0.799^{*}$ & -0.174 & -0.292 \\
\hline Teachers per capita & $0.703^{*}$ & 0.469 & 0.229 \\
\hline Physicians per capita & $0.669^{*}$ & 0.491 & -0.123 \\
\hline Armed forces per capita & 0.328 & 0.299 & 0.088 \\
\hline Educational expenditure per capita & 0.261 & $0.886^{*}$ & 0.105 \\
\hline Health expenditure per capita & 0.321 & $0.835^{*}$ & 0.029 \\
\hline Defence expenditure per soldier & -0.049 & $0.798^{*}$ & 0.099 \\
\hline Health expenditure/GNP & 0.373 & 0.490 & 0.359 \\
\hline School age population in school & 0.075 & -0.103 & $0.741^{*}$ \\
\hline Educational expenditure/GNP & 0.051 & 0.409 & $0.702^{*}$ \\
\hline Eigenvalues & 5.346 & 1.768 & 1.133 \\
\hline \multicolumn{4}{|l|}{ Total sample of countries, 1980} \\
\hline Literacy rate & $0.885^{*}$ & -0.089 & 0.135 \\
\hline School age population in school & $0.851^{*}$ & 0.066 & 0.289 \\
\hline Percentage women in university enrolment & $0.812^{*}$ & 0.159 & 0.023 \\
\hline School age population per teacher & $-0.790^{*}$ & -0.138 & -0.245 \\
\hline Physicians per capita & $0.754^{*}$ & 0.378 & -0.073 \\
\hline Teachers per capita & $0.738^{*}$ & 0.426 & 0.223 \\
\hline Armed forces per capita & 0.479 & 0.406 & -0.121 \\
\hline Educational expenditure per capita & 0.313 & $0.906^{*}$ & 0.144 \\
\hline Defence expenditure per soldier & -0.151 & $0.826^{*}$ & 0.052 \\
\hline Health expenditure per capita & $0.502^{*}$ & $0.687^{*}$ & 0.089 \\
\hline Educational expenditure/GNP & -0.169 & 0.096 & $0.903^{*}$ \\
\hline Health expenditure/GNP & 0.399 & 0.048 & $0.635^{*}$ \\
\hline Eigenvalues & 5.717 & 1.744 & 1.133 \\
\hline \multicolumn{4}{|l|}{${ }^{*}=$ loadings greater than 50 per cent. } \\
\hline \multicolumn{4}{|c|}{$\begin{array}{l}\text { Note: Based on data from[4] (Washington: World Priorities 1991); statistical work based } \\
\text { on an oblique factor rotation using the varimax procedure in } S P S S / P C+\text { Statistics } 4.0 \text { (SPSS, } \\
\text { Chicago, 1990). }\end{array}$} \\
\hline
\end{tabular}

The Impact of Military Expenditures 


\begin{tabular}{|c|c|c|c|c|}
\hline \multirow[t]{2}{*}{$\begin{array}{l}\text { International } \\
\text { Journal } \\
\text { of Manpower } \\
13,3\end{array}$} & $\begin{array}{l}\text { (Factor loadings) } \\
\text { Variable }\end{array}$ & $\begin{array}{c}\text { Factor } 1 \\
\text { Human } \\
\text { capital }\end{array}$ & $\begin{array}{c}\text { Factor } 2 \\
\text { Public } \\
\text { expenditure }\end{array}$ & $\begin{array}{c}\text { Factor } 3 \\
\text { Educational } \\
\text { commitment }\end{array}$ \\
\hline & \multicolumn{4}{|l|}{ Total sample of countries, 1977} \\
\hline \multirow{26}{*}{42} & Literacy rate & $0.900^{*}$ & 0.114 & -0.168 \\
\hline & School age population in school & $0.874^{*}$ & 0.114 & $0.197^{*}$ \\
\hline & Percentage girls in high school & $0.845^{*}$ & 0.066 & 0.042 \\
\hline & School age population per teacher & $0.740^{*}$ & 0.493 & 0.342 \\
\hline & Teachers per capita & $0.691^{*}$ & 0.458 & 0.400 \\
\hline & Health expenditure/GNP & $0.501^{*}$ & 0.031 & 0.426 \\
\hline & Armed forces per capita & 0.158 & $0.810^{*}$ & -0.008 \\
\hline & Health expenditure per capita & 0.225 & $0.707^{*}$ & 0.491 \\
\hline & Physicians per capita & $0.602^{*}$ & $0.696^{*}$ & -0.031 \\
\hline & Educational expenditure/GNP & 0.197 & -0.079 & $0.876^{*}$ \\
\hline & Educational expenditure per capita & 0.004 & $0.486^{*}$ & $0.736^{*}$ \\
\hline & Defence expenditure per soldier & -0.144 & $0.547^{*}$ & $0.558^{*}$ \\
\hline & Eigenvalues & 5.781 & 2.160 & 1.175 \\
\hline & Total sample of countries, 1974 & & & \\
\hline & School age population in school & $0.884^{*}$ & 0.144 & 0.214 \\
\hline & Literacy rate & $0.882^{*}$ & -0.066 & 0.006 \\
\hline & School age population per teacher & $-0.788^{*}$ & -0.124 & -0.138 \\
\hline & Teachers per capita & $0.751^{*}$ & 0.463 & 0.212 \\
\hline & Physicians per capita & $0.701^{*}$ & 0.474 & -0.064 \\
\hline & Educational expenditure per capita & 0.206 & $0.874^{*}$ & 0.236 \\
\hline & Health expenditure per capita & 0.230 & $0.849^{*}$ & 0.300 \\
\hline & Defence expenditure per soldier & -0.085 & $0.753^{*}$ & -0.031 \\
\hline & Armed forces per capita & 0.321 & $0.649^{*}$ & -0.044 \\
\hline & Educational expenditure/GNP & 0.090 & 0.015 & $0.845^{*}$ \\
\hline & Health expenditure/GNP & 0.119 & 0.170 & $0.776^{*}$ \\
\hline & Eigenvalues & 4.913 & 1.824 & 1.293 \\
\hline Table III. & \multirow{2}{*}{\multicolumn{4}{|c|}{$\begin{array}{l}\text { * = loadings greater than } 50 \text { per cent. } \\
\text { Note: Based on data from[4] (Washington: World Priorities 1991); statistical work based } \\
\text { on an oblique factor rotation using the varimax procedure in SPSS/PC+ Statistics } 4.0 \text { (SPSS, } \\
\text { Chicago, 1990). }\end{array}$}} \\
\hline $\begin{array}{l}\text { Patterns of Human } \\
\text { Capital Formation and } \\
\text { Military Participation, } \\
1977 \text { and } 1974\end{array}$ & & & & \\
\hline
\end{tabular}

The individual country factor scores[22] associated with each of the major dimensions (factors) in the data provide some indication of the relative attainment of these dimensions by the individual sample countries:

(1) In general the Arab Gulf countries have had relatively large public expenditures, although their educational commitment over time has not been particularly large, relative to Third World countries as a whole.

(2) The Gulf states have also had significant improvements over time in their human capital development.

(3) These two patterns are present in the other Arab countries, but to a somewhat lesser extent.

In general these results suggest that improved human capital development may be affected by factors other than increased educational expenditures and/or 
educational commitment. Given these patterns and since the Arab countries have significantly larger military participation rates than their non-Arab counterparts, an additional factor analysis was performed separately on each group of countries. Our intent here was to assess to what extent Arab countries have differed from their non-Arab counterparts in their relative use of military participation and programmes in the armed services as an instrument in improving human capital development - particularly the component associated with improved levels of literacy.

The results of the factor analysis (see Tables IV, V and VI) identified several interesting relationships[23]:

(1) As of 1987 (Table IV) the Arab countries showed a strong pattern between the military participation rate (armed forces per capita) and human capital development[24]. In contrast the military participation rate had a very low factor loading in the non-Arab countries. For these countries increases in the armed forces relative to population were largely associated with increased public-sector expenditure on a per capita basis.

(2) In 1980 (Table V) the patterns observed in 1987 were somewhat weaker. However, the military participation rate in the Arab countries still loaded fairly strongly on the human capital dimension. Interestingly, while military participation loaded slightly stronger on the expenditure dimension, it had a negative sign. That is in the Arab world there was a strong association between the military participation rate and levels of literacy and improvement in the teacher-student/population ratios. However, increased military participation was not associated simply with higher levels of public expenditures per capita. Again the military participation rate in the non-Arab countries loaded highest (and positively) on the public expenditure dimension.

(3) The Arab countries (Table VI) began the period under consideration (1974) with the military participation rate largely associated with the share of resources allocated to education (Deger's measure of human capital). At this time increases in the ratio of armed forces to population was not associated with human capital development or with the pattern of public expenditures per capita. In contrast the military participation rate in the non-Arab countries, as in subsequent years, was largely associated with other types of public expenditures per capita.

\section{Conclusions}

While it might seem intuitively obvious that shifting public allocations from military towards educational activities would accelerate human capital development and hence increase a country's long-run growth prospects (while in the case of the Gulf states reducing dependence on foreign workers), the results presented above suggest that this view is too simplistic. Admittedly, this generalization holds for most developing countries, but it does not appear to be an accurate description of the process by which resources are allocated
The Impact of
Military
Expenditures 


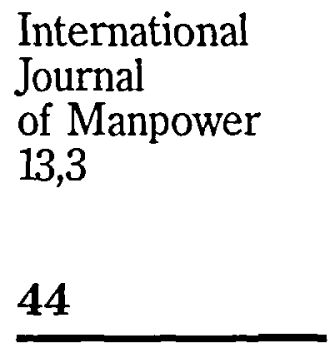

Table IV.

Patterns of Human Capital Formation and Military Participation, 1987

\begin{tabular}{|c|c|c|c|}
\hline $\begin{array}{l}\text { (Factor loadings) } \\
\text { Variable }\end{array}$ & $\begin{array}{c}\text { Factor } 1 \\
\text { Public } \\
\text { expenditure }\end{array}$ & $\begin{array}{c}\text { Factor } 2 \\
\text { Human } \\
\text { capital }\end{array}$ & $\begin{array}{c}\text { Factor } 3 \\
\text { Educational } \\
\text { commitment }\end{array}$ \\
\hline \multicolumn{4}{|l|}{ Arab countries } \\
\hline Health expenditure per capita & $0.903^{*}$ & 0.295 & -0.096 \\
\hline Educational expenditure per capita & $0.859^{*}$ & 0.378 & -0.004 \\
\hline Defence expenditure per soldier & $0.851^{*}$ & 0.003 & 0.041 \\
\hline Physicians per capita & $0.723^{*}$ & 0.568 & -0.074 \\
\hline Health expenditure/GNP & $0.701^{*}$ & 0.309 & 0.429 \\
\hline Literacy rate males & 0.255 & $0.915^{*}$ & 0.081 \\
\hline Literacy rate females & 0.327 & $0.809^{*}$ & -0.137 \\
\hline School age population per teacher & -0.268 & $-0.793^{*}$ & -0.376 \\
\hline Teachers per capita & $0.526^{*}$ & $0.773^{*}$ & 0.160 \\
\hline Armed forces per capita & 0.398 & $0.635^{*}$ & -0.439 \\
\hline Educational expenditure/GNP & 0.210 & 0.304 & $0.752^{*}$ \\
\hline School age population in school & -0.222 & -0.154 & $0.632^{*}$ \\
\hline Eigenvalues & 6.25 & 1.86 & 1.41 \\
\hline Variable & $\begin{array}{l}\text { Factor } 1 \\
\text { Human } \\
\text { capital }\end{array}$ & $\begin{array}{c}\text { Factor } 2 \\
\text { Public } \\
\text { expenditure } \\
\text { per capita }\end{array}$ & $\begin{array}{c}\text { Factor } 3 \\
\text { Educational } \\
\text { commitment }\end{array}$ \\
\hline \multicolumn{4}{|l|}{ Non-Arab countries } \\
\hline Literacy rate males & $0.904^{*}$ & 0.256 & 0.121 \\
\hline School age population per teacher & $-0.888^{*}$ & -0.134 & -0.148 \\
\hline School age population in school & $0.888^{*}$ & 0.206 & 0.238 \\
\hline Literacy rate females & $0.885^{*}$ & 0.281 & 0.160 \\
\hline Teachers per capita & $0.820^{*}$ & 0.303 & 0.207 \\
\hline Physicians per capita & 0.467 & $0.765^{*}$ & 0.043 \\
\hline Educational expenditure per capita & 0.215 & $0.725^{*}$ & $0.525^{*}$ \\
\hline Armed forces per capita & 0.253 & $0.709^{*}$ & 0.009 \\
\hline Health expenditure per capita & 0.166 & $0.706^{*}$ & 0.499 \\
\hline Educational expenditure/GNP & 0.154 & -0.130 & $0.880^{*}$ \\
\hline Health expenditure/GNP & 0.268 & 0.295 & $0.696^{*}$ \\
\hline Defence expenditure per soldier & 0.108 & 0.362 & $0.637^{*}$ \\
\hline Eigenvalues & 6.44 & 1.75 & 1.13 \\
\hline
\end{tabular}

* = loadings greater than 50 per cent.

Note: Based on data from[4] (Washington: World Priorities 1991); statistical work based on an oblique factor rotation using the varimax procedure in SPSS/PC + Statistics 4.0 (SPSS, Chicago, 1990).

in the Arab world. For these countries, increases in the military participation rate appear to take place simultaneously with expended allocations to human capital.

Based on the results presented above, one can only speculate as to the mechanism linking military expenditures and human capital formation in the Arab world. Given the shortages of skilled labour, particularly in the Gulf, 


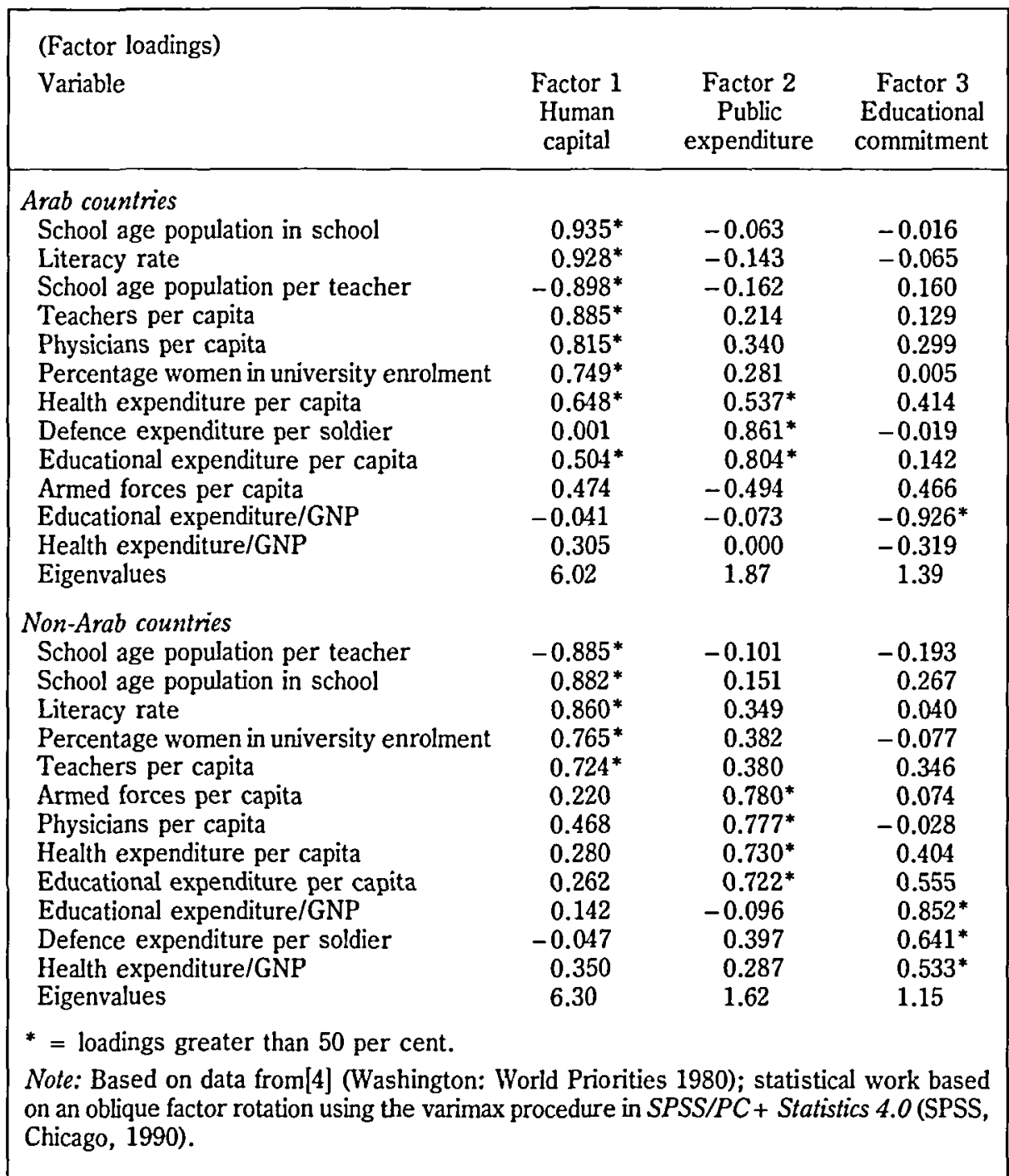

The Impact of Military Expenditures

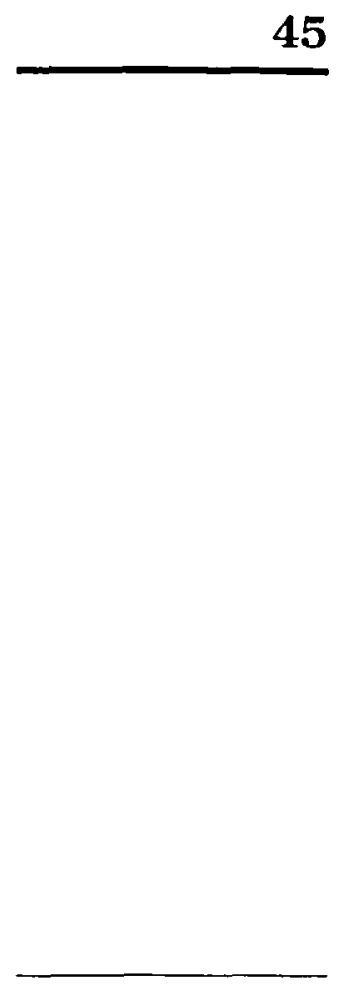

Table V.

Patterns of Human Capital Formation and Military Participation, 1980

governments in that region might assign a very high priority to attracting youths with a high potential for learning into the military services[25]. This could be accomplished by monetary and other incentives. However, since the skilled labour pool is so limited, the private sector might object to sharply increased competition. This is especially the case in the light of a dwindling number of qualified workers.

A more likely situation is one where governments are subsidizing the education of increased numbers of civilians during periods of stepped-up military expenditures with the understanding that upon completion of training those individuals will serve some time in the military. This strategy would allow the 
International Journal of Manpower 13,3

46
Table VI.

Patterns of Human

Capital Formation and Military Participation, 1974
(Factor loadings)

Variable

Factor 1

Factor 2

Factor 3

Human

Public

Educational

capital

expenditure commitment

Arab countries

School age population in school

School age population per teacher

$0.886^{*}$

$-0.087$

0.247

Teachers per capita

Literacy rate

$-0.875^{*}$

0.049

$-0.138$

$0.867^{*}$

0.283

0.219

$0.782^{*}$

$-0.071$

$-0.386$

$0.766^{*}$

0.471

0.280

Health expenditure per capita

0.432

$0.797^{*}$

0.260

Defence expenditure per soldier

0.044

$0.795^{*}$

$-0.270$

0.432

Health expenditure/GNP

Educational expenditure/GNP

$-0.232$

0.004

$0.632^{*}$

0.556

0.584

0.033

0.249

$-0.236^{*}$

0.713

Armed forces per capita

0.290

0.678

4.90

1.97

1.37

Non-Arab countries

Literacy rate

School age population in school

School age population per teacher

Teachers per capita

Defence expenditure per soldier

Educational expenditure per capita

Physicians per capita

Armed forces per capita

Health expenditure per capita

Health expenditure/GNP

Educational expenditure/GNP

Eigenvalues

$\begin{array}{ccc}0.874^{*} & 0.231 & 0.071 \\ 0.871^{*} & 0.185 & 0.261 \\ -0.839^{*} & -0.037 & -0.130 \\ 0.818^{*} & 0.342 & 0.260 \\ -0.066 & 0.782^{*} & 0.065 \\ 0.401 & 0.737^{*} & 0.451 \\ 0.582^{*} & 0.694^{*} & -0.028 \\ 0.361 & 0.685^{*} & -0.118 \\ 0.318 & 0.653^{*} & 0.556^{*} \\ 0.153 & 0.172 & 0.860^{*} \\ 0.122 & -0.079 & 0.810^{*} \\ 5.65 & 1.50 & 1.37\end{array}$

* = loadings greater than 50 per cent.

Note: Based on data from[4] (Washington: World Priorities 1977); statistical work based on an oblique factor rotation using the varimax procedure in $S P S S / P C+$ Statistics 4.0 (SPSS, Chicago, 1990).

military to absorb the large volume of sophisticated weapons flowing into the region, while at the same time not requiring drastic increases in the number of foreign military advisers.

This interpretation is consistent with the results obtained above. Given the relatively high shares of defence and education expenditures in the region (see Table I), allocations to both defence and education could increase fairly rapidly without either category experiencing significant changes in its share of the budget. Because of the low skill levels of the local populations in these countries, it is unlikely that rapid increases in the military participation rate could be absorbed without accelerated training programmes both within and outside the military. 


\section{Notes and References}

1. Best articulated in Cummings, J., Askari, H. and Skinner, M., "Military Expenditures and Manpower Requirements in the Arabian Peninsula", Arab Studies Quarterly, Winter 1980, pp. 38-49.

2. Neuman, S., "Security, Military Expenditures and Socioeconomic Development: Reflections on Iran", Orbis, Fall 1978.

3. The latest date for which comparative data are available.

4. Sivard, R., World Military and Social Expenditures, World Priorities, Washington, various issues. The measures presented by Sivard have varied slightly over the period covered - 1974 to 1987 inclusive. The most notable example is in the literacy rates. In the early years males and females were aggregated into a composite index. Over the last several years these have been compiled on a male/female basis. Also her measure of the propensity for women to attend university or high school has not been included in each of the years examined. The rest of the measures used here are comparable from year to year.

5. Lebovic, J. and Ishaq, A., "Military Burden, Security Needs and Economic Growth in the Middle East", Journal of Conflict Resolution, March 1987, p. 107.

6. Wolf, C., "Economic Success, Stability and the Old International Order", Intemational Security, 1981, p. 89.

7. Weede, E., "Military Participation Ratios, Human Capital Formation, and Economic Growth: A Cross-national Analysis", Journal of Political and Military Sociology, Spring 1983, p. 17.

8. Frederiksen, P.C. and Looney, R.E., "Defence Expenditures and Economic Growth in Developing Countries", Armed Forces and Society, Summer 1983, pp. 633-46.

9. Frederiksen, P.C. and Looney, R.E., "Defense Expenditures and Economic Growth in Developing Countries: Some Further Empirical Evidence", Joumal of Economic Development, July 1982, pp. 112-25.

10. Frederiksen, P.C. and Looney, R.E., "Another Look at the Defence Spending and Development Hypothesis', Defence Analysis, September 1985, pp. 205-10.

11. Looney, R.E. and Frederiksen, P.C., "Defence Expenditures, External Public Debt and Growth in Developing Countries", Joumal of Peace Research, December 1986, pp. 329-38.

12. Looney, R.E., "The Impact of Defence Expenditures on the Saudi-Arabian Economy", Joumal of Arab Affairs, Fall 1987, pp. 198-229.

13. Looney, R.E., "The Role of Military Expenditures in Pre-Revolutionary Iran's Economic Decline", Iranian Studies, Vol. XXI No. 3/4, 1988, pp. 52-83.

14. Mousad, M.R., "Human Resources, Government Education Expenditures and the Military Burden in Less Developed Countries: With Special Reference to the Arab Countries", Bulletin of Arab Research and Studies, No.11, 1984, pp. 35-55.

15. Deger, S., "Human Resources, Government Education Expenditure, and the Military Burden in Less Developed Countries", Joumal of Deteloping Areas, October 1985, pp. 42-3.

16. I am indebted to Geraint Johnes for pointing out this definitional problem.

17. For an overview of this procedure and its interpretation see: Rummel, R.J., Applied Factor Analysis, Northwestern University Press, Evanston, Illinois, 1970.

18. For a description and rationale of this approach see: Adelman, I. and Morse, C.T., Economic Grouth and Social Equity in Developing Countries, Stanford University Press, Stanford, 1967.

19. As evidenced by the factor loading of that variable on the human capital dimension.

20. The original sample of Sivard's developing countries was reduced to 82 owing to missing observations on several of the variables.

21. Factors were selected using the criterion of eigenvalues greater than unity. See[17] for the reasoning underlying this procedure.
The Impact of Military Expenditures 
International Journal of Manpower 13,3
22. Given space limitations, it is not possible to present the entire listing here - tables are available from the author upon request. Factor scores are standardized, that is they are indexes with a mean of zero. As such they provide a comparable measure of relative attainment across the sample countries.

23. Other years were also examined. These included 1977, 1979, 1982 and 1984. Again space limitation prevents their presentation here. Suffice it to say the results of these interim years were essentially what one would expect by extrapolating between the three years presented here. That is for the Arab countries we find a gradual strengthening of the relationship between the military participation rate and public expenditure per capita between 1974 and 1980. Between 1980 and 1987 the pattern shifts towards a greater association between military expenditures and improvements in human capital formation. The non-Arab countries exhibit a high degree of stability between the military participation rate and public expenditures per capita.

24. As evidenced by the relatively high factor loading, 0.635 . Factor loadings are analogous to coefficients of determination in regression analysis.

25. A possibility noted by[16, p. 42]. 